Artigos/Articles

\title{
Harmonia vocálica e coarticulação vogal a vogal em duas variedades do português brasileiro
} Vowel harmony and vowel-to-vowel coarticulation in two varieties of Brazilian Portuguese

\author{
Plinio A. Barbosa ${ }^{1}$ \\ Paula Benassi Papa² \\ Bruno Andrade Silva ${ }^{3}$ \\ Natasha Mourão ${ }^{4}$
}

\section{ABSTRACT}

This work presents a study of Brazilian Portuguese pre-stressed vowels in penultimate, trisyllabic words with four informants, two from Campinas region (South-Eastern) and two from Recife (North-Eastern Brazil). A corpus of 58 familiar and unfamiliar words within carrier phrases evaluated the duration, F1 and F2 frequencies of pre-stressed and stressed vowels. The goal was to examine vowel harmony as a possible consequence of Vowel-to-Vowel anticipatory coarticulation. Results point to asymmetries of vowel harmony: its frequency is higher

1. Universidade Estadual de Campinas, Departamento de Linguística. Campinas, SP-Brasil. https://orcid.org/0000-0001-6317-3548. E-mail: pabarbosa.unicampbr@gmail.com. 2. Universidade Estadual de Campinas, Departamento de Linguística. Campinas, SP Brasil. https://orcid.org/0000-0001-5673-7317.E-mail: paula.papa92@hotmail.com.

3. Universidade Estadual de Campinas, Departamento de Linguística. Campinas, SP Brasil. https://orcid.org/0000-0002-2784-6730. E-mail: bruno.asilva@yahoo.com.br.

4. Universidade Estadual de Campinas, Departamento de Linguística. Campinas, SP Brasil. https://orcid.org/0000-0003-4784-2179. E-mail:nrmmourao@gmail.com. 
in familiar words; in Recife, the harmony with low and mid-low stressed vowels is more frequent; stressed $/ u$ / triggers less harmony than the other stressed vowels and pre-stressed /e/ undergoes more harmony than pre-stressed /o/.

Keywords: Vowel harmony; Brazilian Portuguese; Phonological asymmetry; Acoustic Phonetics.

\section{RESUMO}

Este trabalho apresenta um estudo de vogais pré-tônicas em trissílabos paroxítonos em quatro falantes, sendo dois da região de Campinas e dois do Recife. $O$ corpus de 58 palavras enunciadas em frases-veículo e divididas entre familiares e não familiares avalia as frequências de F1 e F2 e a duração de vogais pré-tônicas e tônicas para investigar a harmonia vocálica como consequência da coarticulação antecipatória. Os resultados apontaram assimetrias quanto à harmonia vocálica: ela ocorre com maior frequência em palavras familiares, com maior frequência disparada por vogal tônica baixa e média-baixa no Recife. Além disso, a tônica /u/ serve de gatilho a um menor número de vogais harmonizadas e a vogal pré-tônica le/ harmoniza mais que /o/.

Palavras-chave: Harmonia vocálica; Português Brasileiro; Assimetria Fonológica; Fonética Acústica.

\section{Introdução}

Segundo Bisol (1981, 1988), a harmonia vocálica em posição prétônica em português brasileiro (doravante $\mathrm{PB}$ ) é o processo segundo o qual as vogais pré-tônicas médias /e, o/ se alçam quando uma vogal tônica contígua é alta. Exemplos comuns são: $\mathrm{p}[\mathrm{i}]$ pino $\sim \mathrm{p}[\mathrm{e}]$ pino, $\mathrm{v}[\mathrm{i}]$ rruga $\sim \mathrm{v}[\mathrm{e}]$ rruga, f[u]rmiga $\sim \mathrm{f}[\mathrm{o}] \mathrm{rmiga}$ e c[u]ruja $\sim \mathrm{c}[\mathrm{o}]$ ruja. Esse processo de alçamento está presente nos primórdios de nossa língua, como demonstra o estudo histórico feito por Bisol (2015).

No entanto, as vogais tônicas podem desencadear abaixamento das médias como em f[o]foca $\sim f[o]$ foca, d[ $[\varepsilon]$ cepa $\sim \mathrm{d}[\mathrm{e}]$ cepa, como observado por Abaurre (1981) para o dialeto capixaba (e.g., $\mathrm{p}[\varepsilon] \mathrm{r}[\varepsilon] \mathrm{r}[\varepsilon] \mathrm{ca}$ ). 
O processo de harmonia vocálica parece estar associado a um gatilho disparado pela produção vindoura da vogal tônica. Fenômenos como o alçamento da pré-tônica em $\mathrm{t}[\mathrm{u}]$ mate e $\mathrm{b}[\mathrm{u}]$ neca ou do abaixa-

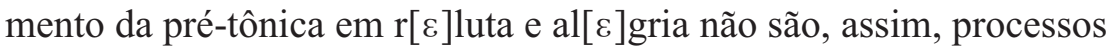
de harmonia vocálica.

É exatamente a essa distinção dos fenômenos a que se referem Collischonn e Silva (2013) ao apontarem processos de abaixamento que interagem com a harmonia vocálica a partir de dados do NURC (Projeto Norma Urbana Culta), com dados acústicos de inquéritos com pessoas com formação universitária em cinco capitais brasileiras: "Os dados do NURC indicam percentuais altos de vogais [E] e [0] pretônicas em Salvador (60\%) e em Recife (47\%) comparados aos do Rio de Janeiro (5\%) e de São Paulo e Porto Alegre (0\%).” Apontam ainda as autoras que "[a] realização aberta pode ser motivada, em parte, por um processo de harmonia das vogais abertas, pois, ao que tudo indica, a vogal /a/ participa como gatilho do processo (Hora 2005; Lee Oliveira 2003).”

Essa taxa elevada de abaixamento da pré-tônica em falantes do Recife é também apontada pelo estudo descritivo de Sandalo (2012), que mostra valores médios de frequência de F1 (primeiro formante, parâmetro correlato da altura) próximos aos valores médios desse parâmetro em tônica baixa seguinte em trissílabos paroxítonos para esse falante recifense. $\mathrm{O}$ falante do Recife abaixa as pré-tônicas /e,o/ independentemente de a média-baixa seguinte ser/\&/ou / /, em comparação com os demais três falantes do Sudeste, como pode ser verificado pelo exame imediato da Tabela 4 desse trabalho para o falante BP4. Mais recentemente, o estudo embasado em estatística inferencial de Kenstowicz e Sandalo (2016) atesta em grande parte a harmonia vocálica com baixas e altas na tônica, embora os modelos de efeitos mistos não tenham sido sistematicamente significativos para o parâmetro F1. Visto que, em geral, há pouca informação sobre harmonia vocálica na fala recifense, é importante examinar mais atentamente o fenômeno em questão nesse dialeto.

Quanto ao processo de alçamento nas pré-tônicas /e, o/ por harmonia, Callou et al. (2009) observam de oitiva que, nas cinco capitais avaliadas pelo projeto NURC, sua porcentagem de ocorrência vai de 22 
(Porto Alegre) a $32 \%$ (Rio de Janeiro), apontando clara preferência por alçamento na pré-tônica gatilhado pela tônica /i/ (78 \%) em relação ao alçamento gatilhado pela tônica /u/ (31 \%). Quanto a qual das vogais médias sofre mais frequentemente o processo de alçamento, parece não haver uma preferência clara, conforme resenham Collischonn e Silva (2013), mostrando que ambas as vogais se alçam com taxas em torno de 40 \% (taxa superior ao do estudo de Callou et al., 2009 acima): "no Rio Grande do Sul, Bisol (1981) observou uma porcentagem de elevação de 38\% para /e/ e 36\% para /o/; Schwindt (2002) chegou a resultados semelhantes: porcentagem de elevação de $36 \%$ para /e/ e $42 \%$ para /o/. Análises recentes de dados do noroeste do estado de São Paulo também assinalaram valores semelhantes: Tenani e Silveira (2008) relatam pesquisa feita com 16 informantes da região de São José do Rio Preto para a qual encontraram porcentagens de elevação de $39 \%$ para /e/ e $41 \%$ para /o/, quando em contexto precedente à vogal alta /i/. Silva (2012) fez uma análise da fala de São José do Norte, no Rio Grande do Sul, a partir dos dados coletados para o estudo de Amaral (2000), e encontrou aplicação de $41 \%$ para /e/ e 43\% para /o/."

Tanto Bisol (1981), para o dialeto do Rio Grande do Sul, quanto Carmo (2011), para o dialeto do interior paulista analisando verbos, observam que a vogal tônica /i/ exerce uma maior influência para o alçamento de /e,o/ pré-tônicos do que a tônica /u/. Nos dados da última autora, por exemplo, não se observou alçamento quando a pré-tônica era /e/ e a tônica /u/ (e.g., "segura"). No entanto, a observação da pronúncia de palavras como "beluga", "texugo", "peluda", em que não se ouve alçamento nos dois primeiros casos, enquanto se ouve no terceiro, sugere que a frequência de uso das palavras pode ser um fator determinante para a ocorrência de alçamento nesses casos como também de forma geral. Em nosso conhecimento, a frequência de uso ou algum fator a ela correlato não foi considerada nos estudos apontados aqui. Sendo assim, um estudo acústico-experimental, em que se avalie o papel dessa e de outras variáveis possivelmente condicionantes do processo, se faz necessário para procurar esclarecer algumas questões ainda pendentes que assinalaremos na seção 3 . Na próxima seção, a harmonia vocálica é enquadrada como processo perceptivo emergente de coarticulação antecipatória da tônica para a pré-tônica, dentro de um modelo fonético de coprodução. 
O estudo desenvolvido aqui se insere no quadro do Projeto Temático "Fronteiras e Assimetrias em Fonologia e Morfologia", coordenado por Filomena S. Sandalo, visando ao esclarecimento de processos fônicos que encontram restrições em determinados contextos (assimetrias). São portanto objetivos deste trabalho: (1) reexaminar a questão da harmonia vocálica na fala recifense; (2) avaliar a influência da familiaridade com a palavra no que se refere à coarticulação vogal-a-vogal; (3) reexaminar, nos dois dialetos de forma comparativa, a frequência de coarticulação e possível harmonia para as pré-tônicas /e,o/; (4) reexaminar, nos dois dialetos de forma comparativa, possíveis diferenças quanto às tônicas que disparam a coarticulação e possível harmonia.

\section{Harmonização vocálica como resultado de processo coarticulatório}

A coarticulação, segundo proposta de Fowler (1980), é o resultado da coprodução de segmentos fônicos, coprodução que faz com que esse segmentos se influenciem mutuamente, muito embora essa influência seja maior da articulação mais extensa (como nos segmentos tônicos) para a menos extensa (como nos segmentos átonos). A coprodução se fundamenta num planejamento interno à língua que estabelece limites para a coarticulação (Whalen 1990). Vários autores demonstram que a coarticulação pode se estender por vários segmentos (cf.: Abry e Lallouache 1995) e incluir mais de uma vogal (Manuel e Krakow 1984). A coprodução de uma vogal tônica com uma vogal pré-tônica possibilita assim haver harmonia como decorrência de coarticulação antecipatória: a tônica influencia a produção da vogal que a precede, independentemente de consoante interveniente. Essa influência pode se dar potencialmente tanto na dimensão da altura quanto do ponto de articulação. No entanto, justamente por ser planejado e implementada na língua, a coarticulação pode ter grau menor ou maior, admitindo inclusive bloqueios no processo.

O grau de coarticulação vogal a vogal é condição necessária para a harmonia vocálica, mas não é condição suficiente. Quando a coarticulação é tal que modifica a qualidade percebida da vogal pré-tônica, então houve harmonização entre as vogais em questão. O grau dessa coarticulação pode ser estudado por meio de medidas das frequências 
de formantes que, indiretamente, avaliam o ponto de articulação (F2) e a altura da língua (F1). Se houver coarticulação ocorrerá, necessariamente, uma aproximação dos valores médios de F1 e/ou F2 da vogal pré-tônica com relação aos valores das mesmas dimensões formânticas da vogal tônica. Concomitantemente, uma análise da duração da vogal pré-tônica pode avaliar se seu eventual alçamento ou abaixamento é acompanhado, respectivamente, por seu encurtamento ou alongamento. Se isso se der, seria mais um indício de que, nessa posição, a vogal recebe ainda essa marca de vogal tônica alta (que é curta em PB) ou baixa (longa em PB).

Diante do exposto, apresentamos em seguida as questões que queremos responder, o corpus que montamos para responder a essas questões e a metodologia para mensuração e análise estatística dos parâmetros acústicos correlatos da coarticulação.

\section{Metodologia}

O corpus é constituído por palavras-chave inseridas nas frases veículo Digo __ baixinho e Baixinho digo __ , para que se possa observar o comportamento dos parâmetros acústicos relacionados à harmonia nessas duas posições no enunciado (medial e final, respectivamente). Todas as palavras-chaves foram produzidas ou não com proeminência, e isso foi eliciado pelo uso de letras maiúsculas (Digo palavra BAIXINHO - não proeminente; Digo PALAVRA baixinho proeminente). Combinando os fatores relativos à posição no enunciado, nível de proeminência, palavra e dialeto com 10 falantes por dialeto e 5 repetições aleatórias de todo o conjunto, dispusemos de um corpus com um total de 23.200 sentenças isoladas ( $=2 \times 2 \times 58 \times 2 \times 10 \times 5$, respectivamente segundo os fatores). Os informantes são jovens universitários gravados em Campinas e no Recife com a colaboração do colega Miguel Oliveira Jr., que selecionou e realizou as gravações com os falantes do Recife na própria capital pernambucana. Foram gravados assim 10 falantes do interior de S. Paulo (região de Campinas) e 10 falantes do Recife, todos entre 20 e 30 anos na época da gravação.

Para o trabalho aqui apresentado, foram inicialmente selecionadas do corpus Banco de Português Project Direct (PUC-SP) palavras na 
condição controle, i.e., que não podem disparar um processo de harmonia por terem tônicas e pré-tônicas idênticas (como beleza, pulula) e na condição teste, com todas as combinações vocálicas possíveis, tanto na sílaba tônica quanto na pré-tônica, ambas com qualidades vocálicas distintas. Todas as palavras selecionadas foram trissílabas paroxítonas terminadas por/a/ no padrão /CV'CVCa/. Essa escolha se fundamenta em permitir uma busca de palavras mais frequentes que tenham ao menos uma pré-tônica no padrão lexical mais frequente do português. A terminação por/a/ também visou facilitar essa frequência, bem como garantir que essa pós-tônica se mantivesse na pronúncia dos falantes, uma vez que as demais pós-tônicas tendem a se ensurdecer. Procurou-se manter o mesmo ponto de articulação depois da vogal tônica e o vozeamento da consoante no início da tônica, pois esses fatores afetam o movimento de F2 e a duração da vogal, respectivamente. A seleção final de palavras dependeu do teste de familiaridade que explicamos a seguir.

As questões relacionadas à harmonia vocálica em pré-tônicas do PB que nos parecem ainda sem resposta adequada, pelo menos do ponto de vista experimental, e que constituem dois dos objetivos de nossa pesquisa são as seguintes.

Questão 1: A influência do dialeto. Tendo em vista que aspectos gerais de alçamento e abaixamento em pré-tônicas interagem com o processo de harmonia vocálica e que, tanto abaixamento quanto alçamento, têm taxa elevada nos dados do NURC de duas capitais nordestinas, o corpus que gravamos é composto de falantes de duas regiões: interior de São Paulo e Recife. A escolha por Recife deve-se ao fato de podermos confirmar ou não o que fora encontrado por Sandalo (2012).

Questão 2: O possível efeito da familiaridade com a palavra pronunciada. Optamos por um estudo composto de palavras de alta e baixa familiaridade, pois palavras não familiares mantêm-se com pronúncia mais próxima à ortografia que palavras familiares. Assim, essa escolha permitirá testar a influência que o uso das palavras pelos falantes tem no processo de harmonia vocálica, i.e., se as palavras familiares tendem a harmonizar, e as não familiares resistiriam ao processo.

A decisão por adotar a familiaridade, e não a frequência de uso como fator condicionante, se deve ao fato de que a segunda depende 
de corpora disponíveis, que são sempre de escopos específicos. Assim, uma palavra como "barriga" pode ter baixa frequência de uso por não ser muito usada na maioria dos corpora disponíveis. Para este trabalho o mais apropriado é considerar a relação da palavra, enquanto item a ser pronunciado, com o falante. Assim, optamos por selecionar as palavras em função de sua familiaridade.

A familiaridade foi calculada a partir de testes com informantes que responderam, para cada palavra selecionada do corpus Banco de Português Project Direct (PUC-SP), uma resposta entre cinco: não conheço, acho que conheço, não sei, acho que conheço e conheço. Para fins de decisão do limiar de familiaridade, cada uma dessas respostas foi recodificada internamente de menos um (-1) a um (1), isto é, com os valores respectivos de $(-1 ;-0,5 ; 0 ; 0,5$ e 1$)$. Os testes foram aplicados em 20 sujeitos pela Internet através da preparação e lançamento pela plataforma Gizmo (https://www.gizmopowered.net/) realizados por Magnum Madruga, aluno de doutorado participante do Projeto Temático referido na Introdução. Em função das seleções feitas pelos sujeitos, as palavras escolhidas como não familiares foram aquelas com mediana -1 (não conheço) com tolerância para média até 0,5 . As palavras familiares foram aquelas com mediana 1 (conheço) com tolerância de média superior a 0,75 . Dentre todas as palavras disponíveis selecionamos aquelas que permitiram obter o máximo de vogais distintas nas posições tônica e pré-tônica. Também mantivemos palavras mencionadas no projeto que serão testadas por terem aparecido na literatura, como "beluga" que será comparada à palavra familiar "verruga", ambas com pré-tônica /e/, seguida de tônica /u/ e começadas por uma consoante labial.

O Quadro 1 mostra as palavras não familiares selecionadas, enquanto o Quadro 2 mostra as palavras familiares. O total de palavras é de 58 . 
Quadro 1 - Palavras não familiares retidas para gravação em frase-veículo

\begin{tabular}{|l|l|l|l|l|l|l|l|}
\hline & \multicolumn{7}{|c|}{ Vogal Tônica } \\
\hline Pré-Tônica & I & e & $\varepsilon$ & a & Ј & o & u \\
\hline i & Pipila & piqueta & & ripassa & didoca & & picula \\
\hline e & pequira & pelega & rebela & & derroga & & beluga \\
\hline a & Papila & paveja & & babata & taboca & pabola & babucha \\
\hline o & Cobija & sobeja & & solapa & dodora & modorra & poluta \\
\hline u & pudica & & & & & & pupula \\
\hline
\end{tabular}

Fonte: Dados da pesquisa

Quadro 2 - Palavras familiares retidas para gravação em frase-veículo

\begin{tabular}{|l|l|l|l|l|l|l|l|}
\hline & \multicolumn{7}{|c|}{ Vogal Tônica } \\
\hline Pré-Tônica & i & e & $\varepsilon$ & a & o & o & u \\
\hline i & birita & & direta & pitada & bitoca & & sinuca \\
\hline e & decida & $\begin{array}{l}\text { deseja/ } \\
\text { beleza }\end{array}$ & $\begin{array}{l}\text { peteca/ } \\
\text { decepa }\end{array}$ & medalha & derrota & & $\begin{array}{l}\text { reluta/ } \\
\text { verruga }\end{array}$ \\
\hline a & tarifa & gazeta & careca & barata & chacota & & sacuda \\
\hline o & comida & cometa & começa & tomada & $\begin{array}{l}\text { fofoca/ } \\
\text { coloca }\end{array}$ & socorra & coruja \\
\hline u & fuzila & muleta & pudera & buchada & & mucosa & futura \\
\hline
\end{tabular}

Fonte: Dados da pesquisa

Os demais fatores manipulados permitiram avaliar tanto o papel da proeminência da palavra no enunciado, como a posição no mesmo para a harmonia vocálica. Com base no desenho experimental exposto acima, as hipóteses de trabalho são:

1. Palavras familiares harmonizam mais que palavras não familiares:

2. A harmonia é semelhante nos dois dialetos, mas está associada ao abaixamento na pré-tônica não motivado pela tônica no dialeto do Recife; 
3. Palavras proeminentes, por serem hiperarticuladas, devem desfavorecer a harmonia vocálica;

4. Não há efeito de posição do enunciado;

5. Pré-tônicas /e,o/ que se alçam para qualidade acústica semelhante à da tônica alta que dispara o processo devem ter duração menor que na condição controle, pois a tônica é uma vogal alta de curta duração, enquanto pré-tônicas /e,o/ que abaixam disparadas por vogais baixas ou médio-baixas devem ter duração maior do que na condição controle, pois a tônica é uma vogal baixa de longa duração.

6. A tônica /u/ serve de gatilho de harmonia com menor frequência que a vogal /i/, no caso de alçamento, evidentemente.

7. As vogais pré-tônicas /e,o/ têm igual frequência de harmonização.

As variáveis dependentes que permitiram avaliar as hipóteses acima são:

1. Duração da vogal em milissegundos. Para responder à hipótese 5.

2. Posição no espaço acústico pelos valores de F1 e F2 com relação às vogais na condição controle e tônicas para avaliar se a vogal pré-tônica se aproxima mais da tônica disparadora ou se é semelhante à vogal na condição controle (em que não há harmonia). Essas medidas, explicitadas abaixo, permitirão responder às hipóteses $1 \mathrm{a} 4$.

3. A contagem do número de vogais harmônicas e de seus gatilhos permitirá responder às hipóteses 6 e 7 .

Para responder a essas hipóteses, comparamos valores médios de F1, F2 e duração das vogais pré-tônicas entre as condições controle e teste. Dessa forma, pode-se determinar se há coarticulação, que se dá quando os valores médios de F1 e F2 nas pré-tônicas são distintos nas duas condições e os valores na condição teste acompanham as características da tônica que segue a pré-tônica. Por exemplo, se o valor de F1 na pré-tônica na condição teste for maior do que na condição controle, significa que a vogal teste é mais baixa do que a vogal controle. 
Se essa vogal é seguida por uma tônica mais baixa que a pré-tônica, então há coarticulação com consequência para a altura. Se, por outro lado, o valor de F2 na pré-tônica na condição teste, for maior do que na condição controle, significa que a vogal teste é mais anterior do que a controle. Se a tônica que segue for vogal mais anterior que a pré-tônica, então há coarticulação com consequência para o ponto de articulação. A harmonia é confirmada a partir de testes de percepção que comprovem, para o caso de /e,o/, se os ouvintes percebem se essas vogais são mais abertas, fechadas ou não variaram em abertura. A distinção entre processo harmônico e uma regra geral de abaixamento se dá quando se verifica que o abaixamento se dá mesmo diante de tônica alta. Raciocínio análogo se aplica quando o valor de F1 na pré-tônica na condição teste é menor do que na condição controle.

Para que todas essas relações sejam validadas experimentalmente, empregamos um teste estatístico inferencial com o fim de avaliar a significância das diferenças entre as médias de cada parâmetro acústico em escrutínio nas duas condições e para cada pré-tônica. O teste mais adequado é o teste $t$ de variáveis independentes. O nível de significância final nas 6 comparações da condição controle com as demais tônicas é de $5 \%$. Assim, usando a correção de Bonferroni, a comparação de cada par controle/teste para determinada pré-tônica requer uma nível de significância de $0,8 \%(=5 \% / 6)$.

Todas as análises acústicas foram obtidas automaticamente pelo software Praat (Boersma e Weenink, 2015), por meio do script VowelParameterComputing, desenvolvido pelo primeiro autor (Barbosa, 2016) e disponível para pesquisa por solicitação. Os intervalos acústicos das vogais foram determinados pelo padrão de aparecimento (margem esquerda) e desaparecimento (margem direita) da energia de F2. Os valores das frequências dos formantes foram determinados pelo algoritmo LPC (Burg) no Praat.

\section{Resultados quanto às vogais pré-tônicas}

Passaremos ao exame dos resultados obtidos para os quatro locutores para os parâmetros de F1, F2 e duração. Um teste inicial mostrou que não há diferença estatística das médias de F1 e F2 quanto às variáveis 
nível de proeminência e posição no enunciado. Por esse motivo, todos os resultados consideram as médias dos parâmetros independentemente dessas condições, ou seja, os dados foram agrupados para as duas posições no enunciado e os dois níveis de proeminência.

A Tabela 1 mostra os resultados das médias de F1 e F2 em Hertz das 5 pré-tônicas para o sujeito LR, feminino, da região de Campinas, nas condições controle (valores da primeira coluna) e teste (demais colunas, indicando a tônica da sílaba seguinte), tanto para palavras familiares quanto não familiares.

Para cada vogal e familiaridade de palavra, as médias de F1 são os valores da primeira linha e as médias de F2, os valores da segunda linha. A média de cada um desses dois parâmetros se refere ao cálculo para todas as pré-tônicas no interior dos subconjuntos formados por todas as palavras familiares e por todas as palavras não familiares. Somente as três últimas repetições das frases gravadas foram consideradas, por terem sido pronunciadas sem hesitações ou pausas indevidas quando da leitura.

Tabela 1 - Médias (Hz) de F1 e F2 das 5 pré-tônicas nas condições controle e teste para a locutora LR, do interior paulista. Seg. significa "seguinte", assim nas demais tabelas

\begin{tabular}{|c|c|c|c|c|c|c|}
\hline média $(\mathrm{Hz}) / \mathrm{i} /$ & \multicolumn{6}{|c|}{ Palavras familiares } \\
\hline Controle & seg. /e/ & $\operatorname{seg} . \mid \varepsilon /$ & seg. /a/ & seg. /o/ & seg. /o/ & seg. $/ u /$ \\
\hline 417 & - & 447 & 404 & 413 & - & 483 \\
\hline 2564 & - & 2304 & 2468 & 2394 & - & 2296 \\
\hline média $(\mathrm{Hz}) / \mathrm{i} /$ & \multicolumn{6}{|c|}{ Palavras não-familiares } \\
\hline Controle & seg. /e/ & seg. $\mid \varepsilon /$ & seg. /a/ & seg. /o/ & seg. $/ 0 /$ & seg. $/ u /$ \\
\hline 396 & 388 & - & 405 & 411 & - & 395 \\
\hline 2434 & 2558 & - & 2574 & 2192 & - & 2525 \\
\hline média $(\mathrm{Hz}) / \mathrm{e} /$ & \multicolumn{6}{|c|}{ Palavras familiares } \\
\hline Controle & seg. /i/ & seg. $\mid \varepsilon /$ & seg. /a/ & seg. /o/ & seg. $/ 0 /$ & seg. $/ u /$ \\
\hline 496 & 438 & 529 & 602 & 544 & - & 500 \\
\hline 2120 & 2105 & 2053 & 2227 & 2268 & - & 2072 \\
\hline média $(\mathrm{Hz}) / \mathrm{e} /$ & \multicolumn{6}{|c|}{ Palavras não-familiares } \\
\hline Controle & seg. /i/ & $\operatorname{seg} . \mid \varepsilon /$ & seg. /a/ & seg. /o/ & seg. $/ 0 /$ & seg. $/ \mathrm{u} /$ \\
\hline 521 & 442 & 630 & - & 572 & - & 476 \\
\hline 2241 & 2429 & 2112 & - & 2259 & - & 2074 \\
\hline
\end{tabular}




\begin{tabular}{|c|c|c|c|c|c|c|}
\hline média $(\mathrm{Hz}) / \mathrm{a} /$ & \multicolumn{6}{|c|}{ Palavras familiares } \\
\hline Controle & seg. /i/ & seg. /e/ & seg. $/ \varepsilon /$ & seg. /o/ & seg. $/ 0 /$ & seg. /u/ \\
\hline 844 & 769 & 658 & 798 & 747 & - & 717 \\
\hline 1810 & 1931 & 1904 & 1928 & 1735 & - & 1653 \\
\hline média $(\mathrm{Hz}) / \mathrm{a} /$ & \multicolumn{6}{|c|}{ Palavras não-familiares } \\
\hline Controle & seg. /i/ & seg. /e/ & $\operatorname{seg} . / \varepsilon /$ & seg. /o/ & seg. $/ 0 /$ & seg. /u/ \\
\hline 803 & 763 & 723 & - & 824 & 767 & 736 \\
\hline 1521 & 1418 & 1546 & - & 1704 & 1331 & 1417 \\
\hline média $(\mathrm{Hz}) / \mathrm{o} /$ & \multicolumn{6}{|c|}{ Palavras familiares } \\
\hline Controle & seg. /i/ & seg. /e/ & seg. $/ \varepsilon /$ & seg. /a/ & seg. $/ \mathrm{J} /$ & seg. /u/ \\
\hline 532 & 529 & 552 & 651 & 657 & 610 & 529 \\
\hline 1155 & 937 & 970 & 1021 & 1140 & 972 & 1076 \\
\hline média $(\mathrm{Hz}) / \mathrm{o} /$ & \multicolumn{6}{|c|}{ Palavras não-familiares } \\
\hline Controle & seg. /i/ & seg. /e/ & seg. $/ \varepsilon /$ & seg. /a/ & seg. $/ \mathrm{J} /$ & seg. /u/ \\
\hline 563 & 485 & 542 & - & 639 & 557 & 510 \\
\hline 1034 & 917 & 1233 & - & 1076 & 1371 & 947 \\
\hline média $(\mathrm{Hz}) / \mathrm{u} /$ & \multicolumn{6}{|c|}{ Palavras familiares } \\
\hline Controle & seg. /i/ & seg. /e/ & seg. $\mid \varepsilon /$ & seg. /a/ & seg. $/ \mathrm{J} /$ & seg. $/ 0 /$ \\
\hline 422 & 458 & 519 & 511 & 455 & 549 & - \\
\hline 1230 & 1289 & 1031 & 1229 & 1620 & 997 & - \\
\hline média $(\mathrm{Hz}) / \mathrm{u} /$ & \multicolumn{6}{|c|}{ Palavras não-familiares } \\
\hline Controle & seg. /i/ & seg. /e/ & seg. $/ \varepsilon /$ & seg. /a/ & seg. $/ \mathrm{J} /$ & seg. $/ 0 /$ \\
\hline 464 & 451 & - & - & - & - & - \\
\hline 936 & 1411 & - & - & - & - & - \\
\hline
\end{tabular}

Fonte: Dados da pesquisa

Os valores em negrito para as vogais na condição de teste são significativos para $p<0,008$. Essa significância se refere à diferença entre as médias de cada parâmetro nas condições controle e teste. Por exemplo, na Tabela 1, o valor médio de F2 de $2304 \mathrm{~Hz}$ para a vogal pré-tônica /i/ diante da tônica /\&/ é significativo porque essa média é significativamente distinta da média de F2 da mesma vogal /i/ na situação controle, com média de F2 de $2564 \mathrm{~Hz}$, conforme assinala a tabela.

Assim, examinando a Tabela 1, para as vogais pré-tônicas /e/ e /o/, observa-se um maior número de diferenças estatísticas significativas para F1, correlato da altura: LR abaixa /e/ e /o/ diante das tônicas baixas 
e as eleva diante das tônicas altas, com maior frequência nas palavras familiares. No entanto, no caso da vogal pré-tônica /o/ em palavra familiar, ela não se eleva diante das vogais altas, se posteriorizando independentemente da tônica (com exceção de /a u/). De modo geral, em relação à distância com a tônica, as pré-tônicas /o/ na condição de teste, particularmente nas palavras familiares, estão mais próximas da baixa /o/, conforme pode-se ver nas Figs. 1 e 2. Em todas as figuras, as setas indicam a direção principal de mudança da posição média das pré-tônicas controle para as pré-tônicas teste.

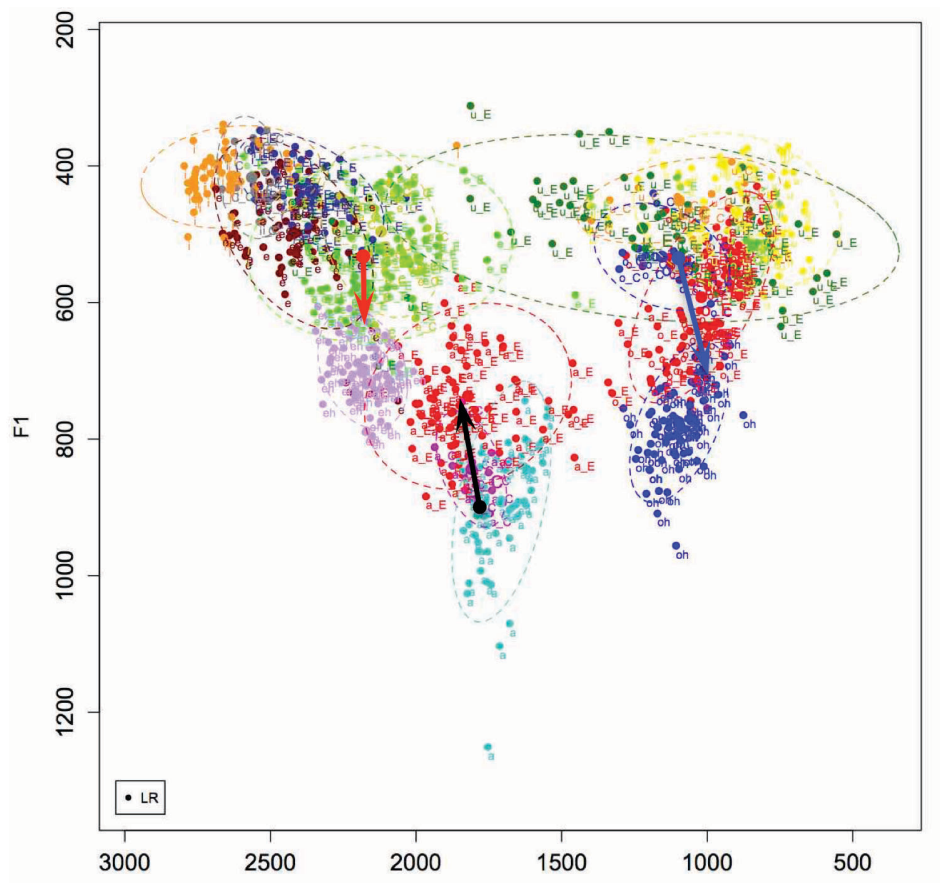

Figura 1 - Espaço acústico F1 x F2 em Hertz de LR (feminino, SP) para palavras familiares. Vogais pré-tônicas na condição controle têm seus símbolos acrescidos de “_C”, enquanto, na condição teste, estão acrescidos de "E". As tônicas não têm nenhum acréscimo aos símbolos. "eh" representa /\&/ e "oh" representa /\%/. 


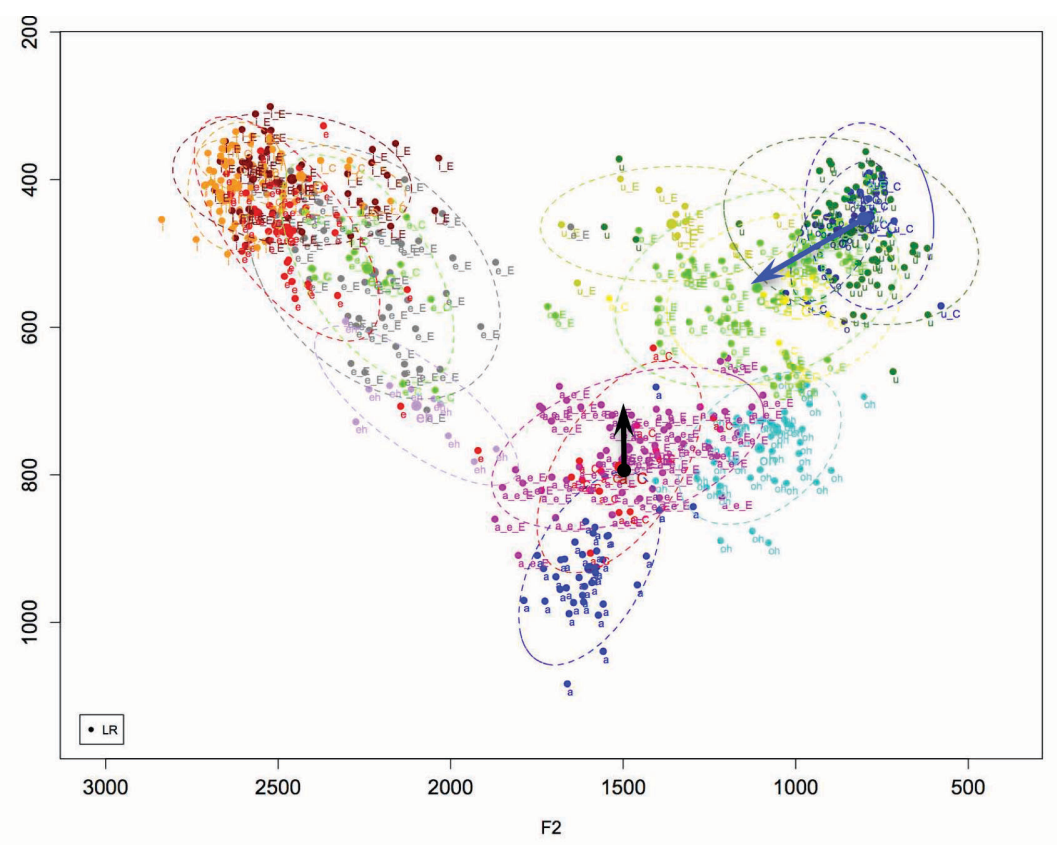

Figura 2 - Espaço acústico F1 x F2 em Hertz de LR (feminino, SP) para palavras não familiares.

Quanto à pré-tônica /i/, essa não sofre variação de altura em nenhuma tipo de palavra, a não ser posteriorização nas palavras familiares (ou seja, se centraliza, como se vê na Fig.1).

Nesta locutora, a vogal /a/ pré-tônica é a que mais sofre coarticulação nas palavras familiares: é mais alta (porque a média de F1 é significativamente menor) diante de todas as tônicas e mais anterior diante das anteriores, o que se vê nos pontos "a_E" da Fig. 1. Já nas não familiares, /a/ se alça diante de /e/ e /u/, se posterioriza diante de /o/ e se anterioriza diante de / /, o que se vê na Fig. 2.

Ainda para esta locutora, a vogal pré-tônica /u/ não sofre, em média, nenhum tipo de coarticulação nas palavras familiares e não familiares do corpus, muito embora o espalhamento de sua realização nas palavras familiares seja notório, como se vê na Fig. 1, em que ocupa tanto a região mais central alta do espaço acústico quanto a mais periférica, à direita na figura. 
A Tabela 2 mostra os resultados das médias de F1 e F2 em Hertz das 5 pré-tônicas para o sujeito RS, masculino, da região de Campinas, nas mesmas condições descritas acima.

Examinando a Tabela 2 para as vogais pré-tônicas /e/ e /o/, observase um maior número de diferenças estatísticas significativas para F1 para /e/ e um número equivalente de diferenças estatísticas para F1 e F2 no caso de /o/. Quanto a /e/, RS a abaixa diante das tônicas baixas e a eleva diante de /i/ (nas palavras familiares). Além disso, posterioriza essa mesma vogal diante de $/ \varepsilon \supset \mathrm{u} /$ nos dois tipos de palavras. A prétônica /o/ abaixa diante de vogal baixa e meio-baixa e se posterioriza diante de /i e $ว \mathrm{u} /$ nas palavras familiares, enquanto nas não familiares ela se coarticula segundo a altura das vogais /i a $\supset \mathrm{u} /$ e se anterioriza diante de /e a J/, o que não parece revelar um padrão homogêneo. De modo geral, em relação à distância da tônica, as pré-tônicas /e o/ na condição de teste, mais ainda nas palavras familiares do que nas não familiares, se aproximam respectivamente de /ع $\mathrm{J} /$, conforme pode-se ver nas Figs. 3 e 4.

Tabela 2 - Médias (Hz) de F1 e F2 das 5 pré-tônicas nas condições controle e teste para o locutor RS, do interior paulista

\begin{tabular}{|c|c|c|c|c|c|c|}
\hline média $(\mathrm{Hz})$ /i/ & \multicolumn{6}{|c|}{ Palavras familiares } \\
\hline Controle & seg. /e/ & seg. $\mid \varepsilon /$ & seg. /a/ & seg. $/ \mathrm{J} /$ & seg. $/ 0 /$ & seg. $/ u /$ \\
\hline 270 & 261 & 354 & 298 & 295 & - & 321 \\
\hline 2211 & 2203 & 2059 & 2098 & 2102 & - & 1990 \\
\hline média $(\mathrm{Hz}) / \mathrm{i} /$ & \multicolumn{6}{|c|}{ Palavras não familiares } \\
\hline Controle & seg. /e/ & seg. $\mid \varepsilon /$ & seg. /a/ & seg. $/ 0 /$ & seg. $/ 0 /$ & seg. $/ u /$ \\
\hline 257 & - & - & 276 & 310 & - & 259 \\
\hline 2010 & - & - & 2147 & 1921 & - & 1941 \\
\hline média $(\mathrm{Hz}) / \mathrm{e} /$ & \multicolumn{6}{|c|}{ Palavras familiares } \\
\hline Controle & seg. /i/ & seg. $\mid \varepsilon /$ & seg. /a/ & seg. $/ 2 /$ & seg. $/ 0 /$ & seg. /u/ \\
\hline 355 & 343 & 404 & 442 & 413 & - & 357 \\
\hline 1974 & 1968 & 1889 & 1988 & 1965 & - & 1912 \\
\hline média $(\mathrm{Hz}) / \mathrm{e} /$ & \multicolumn{6}{|c|}{ Palavras não familiares } \\
\hline Controle & seg. /i/ & seg. $/ \varepsilon /$ & seg. /a/ & seg. $/ 0 /$ & seg. $/ 0 /$ & seg. /u/ \\
\hline 362 & 347 & 452 & - & 388 & - & 349 \\
\hline 2121 & 2142 & 1882 & - & 1962 & - & 1855 \\
\hline
\end{tabular}




\begin{tabular}{|c|c|c|c|c|c|c|}
\hline média $(\mathrm{Hz}) / a /$ & \multicolumn{6}{|c|}{ Palavras familiares } \\
\hline Controle & seg. /i/ & seg. /e/ & $\operatorname{seg} . / \varepsilon /$ & seg. $/ \mathrm{J} /$ & seg. $/ 0 /$ & seg. /u/ \\
\hline 783 & 770 & 797 & 778 & 687 & - & 746 \\
\hline 1348 & 1540 & 1591 & 1494 & 1332 & - & 1372 \\
\hline média $(\mathrm{Hz}) / a /$ & \multicolumn{6}{|c|}{ Palavras não familiares } \\
\hline Controle & seg. /i/ & seg. /e/ & $\operatorname{seg} . \mid \varepsilon /$ & $\operatorname{seg} . / \mathrm{J} /$ & seg. $/ \mathrm{o} /$ & seg. /u/ \\
\hline 725 & 720 & 679 & - & 750 & 710 & 664 \\
\hline 1110 & 1142 & 1204 & - & 1221 & 1080 & 1105 \\
\hline média $(\mathrm{Hz}) / \mathrm{o} /$ & \multicolumn{6}{|c|}{ Palavras familiares } \\
\hline Controle & seg. /i/ & seg. /e/ & seg. $/ \varepsilon /$ & seg. /a/ & seg. $/ \mathrm{J} /$ & seg. /u/ \\
\hline 378 & 387 & 421 & 497 & 483 & 457 & 353 \\
\hline 930 & 829 & 856 & 996 & 955 & 886 & 861 \\
\hline média $(\mathrm{Hz}) / \mathrm{o} /$ & \multicolumn{6}{|c|}{ Palavras não familiares } \\
\hline Controle & seg. /i/ & seg. /e/ & $\operatorname{seg} . / \varepsilon /$ & seg. /a/ & seg. $/ 0 /$ & seg. $/ u /$ \\
\hline 383 & 374 & 399 & - & 502 & 397 & 364 \\
\hline 847 & 847 & 985 & - & 933 & 1022 & 831 \\
\hline média $(\mathrm{Hz}) / \mathrm{u} /$ & \multicolumn{6}{|c|}{ Palavras familiares } \\
\hline Controle & seg. /i/ & seg. /e/ & seg. $\mid \varepsilon /$ & seg. /a/ & seg. $/ \partial /$ & seg. $/ 0 /$ \\
\hline 310 & 311 & 354 & 333 & 315 & 376 & - \\
\hline 983 & 983 & 957 & 956 & 1012 & 1091 & - \\
\hline média $(\mathrm{Hz}) / \mathrm{u} /$ & \multicolumn{6}{|c|}{ Palavras não familiares } \\
\hline Controle & seg. /i/ & seg. /e/ & seg. $\mid \varepsilon /$ & seg. /a/ & seg. /o/ & seg. /o/ \\
\hline 300 & 290 & - & - & - & - & - \\
\hline 750 & 978 & - & - & - & - & - \\
\hline
\end{tabular}

Fonte: Dados da pesquisa 
35.2

2019

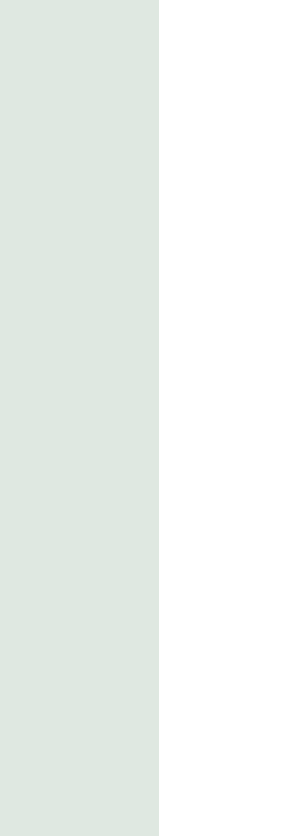

Figura 3 - Espaço acústico F1 x F2 em Hertz de RS (masculino, SP) para pa-

lavras familiares

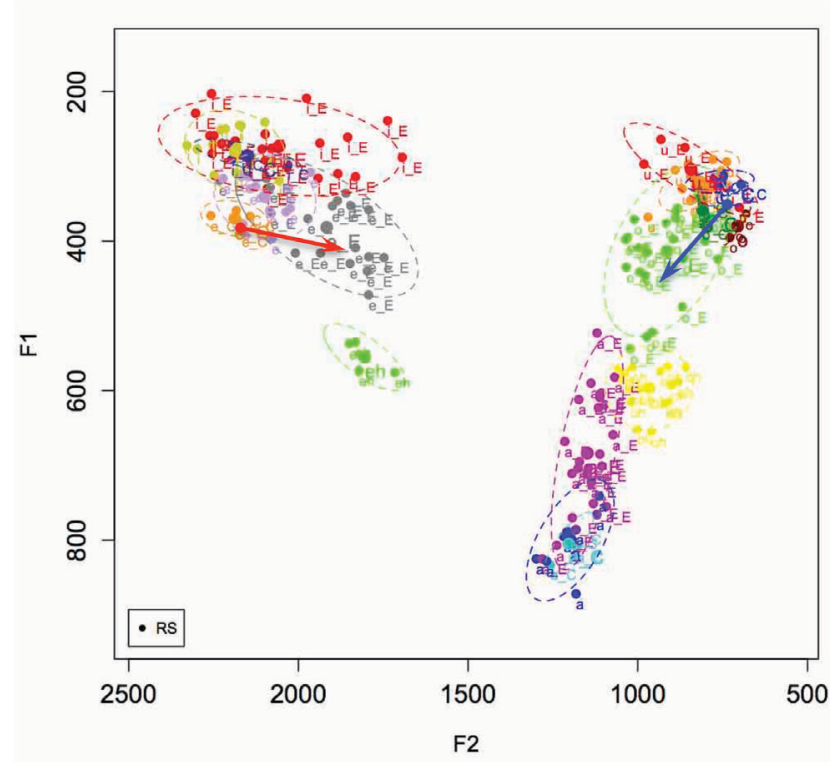

Figura 4 - Espaço acústico F1 x F2 em Hertz de RS (masculino, SP) para pala-

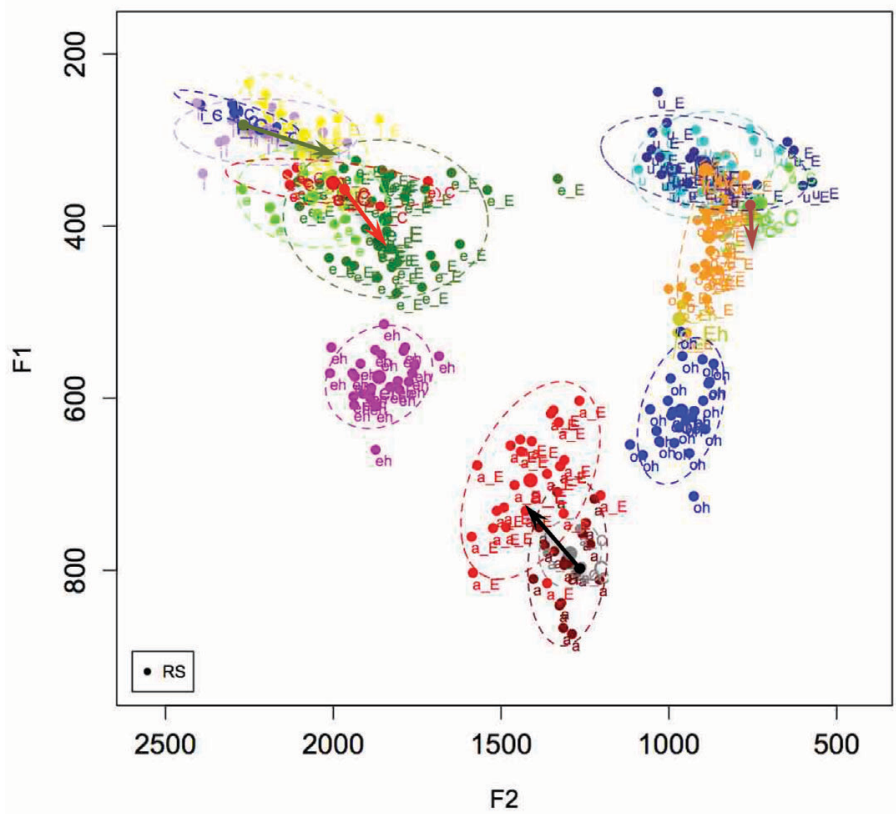

vras não familiares. 
Neste sujeito, a pré-tônica /i/ se posterioriza (cf. Fig. 3) e abaixa para / $₹$ ว u/ nas palavras familiares, enquanto nas não familiares apenas se abaixa com /a ऽ/. Sua pré-tônica /a/ em geral não tem sua altura média alterada, embora se anteriorize diante de tônicas diferentes, sendo no caso das não familiares diante de / //, o que é uma dissimilação. A anteriorização de /a/ pode ser vista nas palavras familiares na Fig. 3, o que não ocorre na Fig. 4 (palavras não familiares). Ainda para esse locutor, a vogal pré-tônica /u/ sofre abaixamento diante de /e $\varepsilon$ o/ nas palavras familiares.

A Tabela 3 mostra os resultados da média de F1 e F2 em Hertz das 5 pré-tônicas para o sujeito $\mathrm{S} 1$ feminino do Recife, nas mesmas condições descritas acima.

Examinando a Tabela 3 para as vogais pré-tônicas /e/ e/o/, observase um maior número de diferenças estatísticas para F1. Para ambas as vogais, ocorre abaixamento diante de tônicas baixas e médio-baixas, independentemente de familiaridade da palavra, o que se vê nas Figs. 5 e 6 . Também ocorre nas familiares diante de /u/. A vogal /o/ se posterioriza nas palavras familiares diante de todas as tônicas com exceção de /a/. Isso indica que, diante dessas vogais, /o/ foi realizada como uma vogal mais aberta, porém mais posterior do que /っ/, como se vê na Fig 5. Nas não familiares é pronunciada como $/ \mathrm{J} /$, por ter se anteriorizado e abaixado (isso se vê nas Figs. 5 e 6, onde ocupa mesma região que /o/). O mesmo ocorre para a vogal /e/, que se realiza como uma vogal mais aberta que /e/, porém com mesmo ponto de articulação, a não ser diante de $/ \varepsilon /$, contexto que sugere ser pronunciada como essa tônica, ocupando seu espaço acústico, o que difere dos locutores de São Paulo.

De modo geral, para essa locutora, /a/ se alça e anterioriza nas palavras familiares, sendo apenas seu ponto de articulação afetado pelas posteriores / $/ \mathrm{J}$ ( se anterioriza) e /o/ (se posterioriza). As alturas de /i/ e /u/ não são globalmente afetadas pelas tônicas nessa locutora, embora tanto posteriorização quanto anteriorização são encontradas diante de / / / (posteriorização no caso de familiares). Tanto /i/ tônico anterioriza /u/ pré-tônico em não familiar, quanto /u/ tônico posterioriza /i/ prétônico em palavra familiar. Esses fenômenos podem ser vistos nas Figs 5 e 6 também. Essas figuras ainda revelam a extrema variabilidade de /e/ pré-tônico diante das tônicas, ocupando todo o espaço de /\&/, porém com maior amplitude de variação. O mesmo ocorre com /o/ em relação a /Ј/, embora com menor amplitude de variação. 
Tabela 3 - Médias (Hz) de F1 e F2 das 5 pré-tônicas nas condições controle e teste para a locutora $\mathrm{S} 1$, do Recife

\begin{tabular}{|c|c|c|c|c|c|c|}
\hline média $(\mathrm{Hz}) / \mathrm{i} /$ & \multicolumn{6}{|c|}{ Palavras familiares } \\
\hline Controle & seg. /e/ & $\operatorname{seg} . \mid \varepsilon /$ & seg. /a/ & seg. $/ \partial /$ & seg. $/ 0 /$ & seg. /u/ \\
\hline 454 & - & 463 & 471 & 469 & - & 496 \\
\hline 2658 & - & 2550 & 2483 & 2475 & - & 2455 \\
\hline média $(\mathrm{Hz}) / \mathrm{i} /$ & \multicolumn{6}{|c|}{ Palavras não familiares } \\
\hline Controle & seg. /e/ & $\operatorname{seg} . \mid \varepsilon /$ & seg. /a/ & seg. / / / & seg. $/ 0 /$ & seg. /u/ \\
\hline 454 & 465 & - & 450 & 451 & - & 474 \\
\hline 2333 & 2450 & - & 2643 & 2467 & - & 2424 \\
\hline média $(\mathrm{Hz}) / \mathrm{e} /$ & \multicolumn{6}{|c|}{ Palavras familiares } \\
\hline Controle & seg. /i/ & seg. $\mid \varepsilon /$ & seg. /a/ & seg. /o/ & seg. $/ 0 /$ & seg. /u/ \\
\hline 522 & - & 707 & 728 & 690 & - & 556 \\
\hline 2138 & - & 2000 & 2057 & 2020 & - & 2108 \\
\hline média $(\mathrm{Hz}) / \mathrm{e} /$ & \multicolumn{6}{|c|}{ Palavras não familiares } \\
\hline Controle & seg. /i/ & seg. $/ \varepsilon /$ & seg. /a/ & seg. $/ 0 /$ & seg. $/ 0 /$ & seg. /u/ \\
\hline 539 & 527 & 722 & - & 711 & - & 514 \\
\hline 2098 & 2288 & 2039 & - & 1982 & - & 2081 \\
\hline média $(\mathrm{Hz}) / \mathrm{a} /$ & \multicolumn{6}{|c|}{ Palavras familiares } \\
\hline Controle & seg. /i/ & seg. $/ e /$ & seg. $\mid \varepsilon /$ & seg. / / / & seg. $/ 0 /$ & seg. /u/ \\
\hline 956 & 956 & 779 & 954 & 863 & - & 848 \\
\hline 1609 & 1734 & 1756 & 1714 & 1593 & - & 1583 \\
\hline média $(\mathrm{Hz}) / \mathrm{a} /$ & \multicolumn{6}{|c|}{ Palavras não familiares } \\
\hline Controle & seg. /i/ & seg. $/ \mathrm{e} /$ & seg. $\mid \varepsilon /$ & seg. $/ \partial /$ & seg. $/ 0 /$ & seg. /u/ \\
\hline 852 & 866 & 837 & - & 877 & 852 & 830 \\
\hline 1442 & 1428 & 1452 & - & 1526 & 1364 & 1425 \\
\hline média $(\mathrm{Hz}) / \mathrm{o} /$ & \multicolumn{6}{|c|}{ Palavras familiares } \\
\hline Controle & seg. /i/ & seg. /e/ & seg. $\mid \varepsilon /$ & seg. /a/ & seg. /o/ & seg. /u/ \\
\hline 585 & 564 & 567 & 685 & 722 & 738 & 520 \\
\hline 1160 & 998 & 999 & 1061 & 1120 & 1097 & 987 \\
\hline média $(\mathrm{Hz}) / \mathrm{o} /$ & \multicolumn{6}{|c|}{ Palavras não familiares } \\
\hline Controle & seg. /i/ & seg. /e/ & seg. $\mid \varepsilon /$ & seg. /a/ & seg. /o/ & seg. /u/ \\
\hline 548 & 545 & 562 & - & 763 & 718 & 532 \\
\hline 982 & 1002 & 1158 & - & 1231 & 1253 & 968 \\
\hline média $(\mathrm{Hz}) / \mathrm{u} /$ & \multicolumn{6}{|c|}{ Palavras familiares } \\
\hline Controle & seg. /i/ & seg. /e/ & seg. $/ \varepsilon /$ & seg. /a/ & seg. /o/ & seg. /o/ \\
\hline 528 & 501 & 527 & 508 & 477 & 507 & - \\
\hline 952 & 1010 & 873 & 907 & 1109 & 848 & - \\
\hline média $(\mathrm{Hz}) / \mathrm{u} /$ & \multicolumn{6}{|c|}{ Palavras não familiares } \\
\hline Controle & seg. /i/ & seg. $/ \mathrm{e} /$ & seg. $\mid \varepsilon /$ & seg. /a/ & seg. $/ \mathrm{s} /$ & seg. $/ 0 /$ \\
\hline 509 & 510 & - & - & - & - & - \\
\hline 846 & 979 & - & - & - & - & - \\
\hline
\end{tabular}

Fonte: Dados da pesquisa 


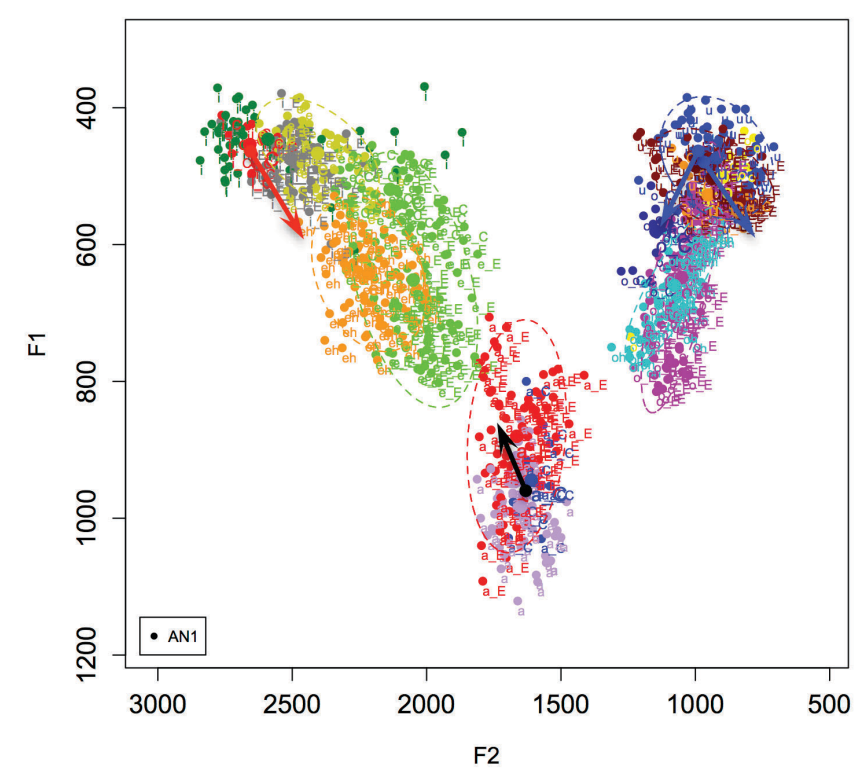

Figura 5 - Espaço acústico F1 x F2 em Hertz de S1 (feminino, PE) para palavras familiares.

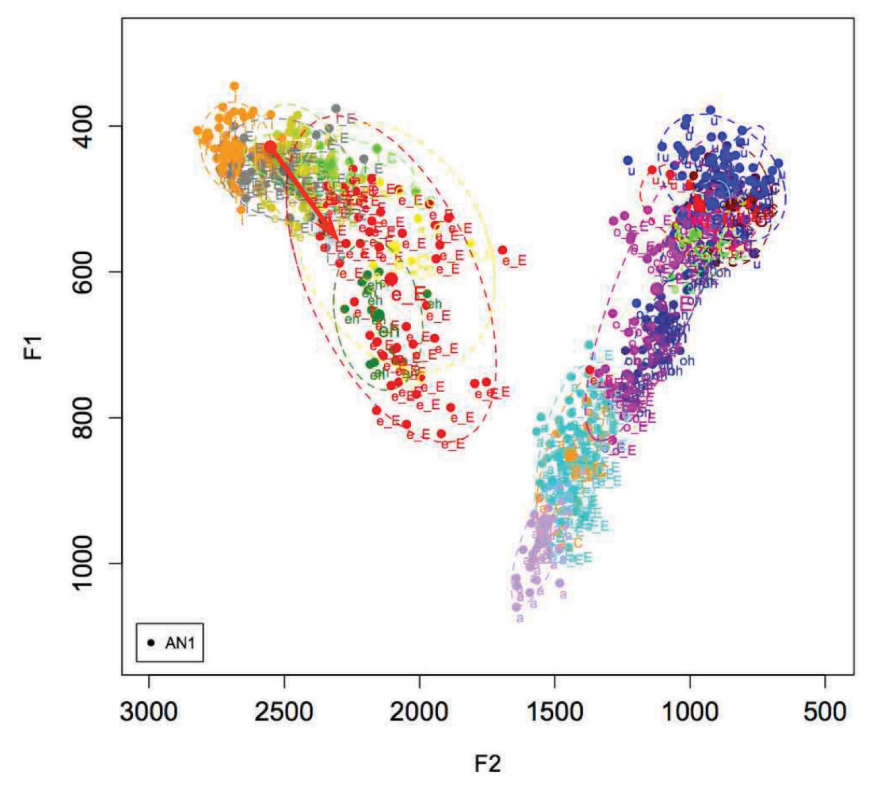

Figura 6 - Espaço acústico F1 x F2 em Hertz de S1 (feminino, PE) para palavras não familiares. 
A Tabela 4 mostra os resultados da média de F1 e F2 em Hertz das 5 pré-tônicas para o sujeito S4 feminino do Recife, nas mesmas condições descritas acima.

Examinando a Tabela 4 para a vogal pré-tônica /e/ em palavras familiares, observa-se um maior número de diferenças estatísticas para $\mathrm{F} 1$, indicando abaixamento da vogal diante de / $/$ a $\mathrm{J} /$ (e anteriorização diante de /i/, como mostra o valor significativo da diferença da média de F2 de /e/ diante dessa tônica). Já para palavras não familiares, a vogal tende para uma vogal próxima a /i/diante de /i/ e para /u/ diante de /u/. Quanto à pré-tônica /o/ nas palavras familiares, ela se abaixa significativamente apenas diante de /a/ e / $/ \mathrm{J}$, enquanto se posterioriza diante de todas as vogais tônicas com exceção de /a/, o que pode assinalar sua aproximação da vogal/u/, com exceção das palavras com /a/ na tônica. A situação nas não familiares não é clara, embora a vogal/o/ tenda para o centro do espaço acústico diante de /e/ tônico. Além disso, diante de /i/ se alça e diante de /u/ se posterioriza. As figuras 7 e 8 mostram as posições dessas vogais com relação a tônicas e vogais de controle. Observe-se que essas vogais ocupam o espaço das médio-baixas.

De modo geral, para essa locutora, /a/ se alça diante de /e o u/ nas familiares e diante de /i o/ nas não familiares. Essa mesma vogal se anterioriza diante de /i \&/ nas palavras familiares. As alturas de /i/ e /u/ não são globalmente afetadas pelas tônicas nessa locutora, a não ser o abaixamento de /u/ diante de / $/$ / nas familiares e o de /i/ diante de / $/$ / (nas palavras familiares /i/ se posterioriza diante de /u/). Essa mesma pré-tônica/u/ é realizada de forma muito anteriorizada por essa locutora, certamente por conta da coarticulação com as consoantes seguintes, que são coronais. Assim, parece exibir um processo dissimilatório diante de /e $\varepsilon$ a/ nas palavras familiares. embora tanto posteriorização quanto anteriorização são encontradas para / / (posteriorização no caso de familiares). Tanto /i/ tônico anterioriza /u/ pré-tônico em não familiar, quanto /u/ tônico posterioriza /i/ pré-tônico em palavra familiar. Esses movimentos podem ser vistos nas Figs 7 e 8 também. As figuras também revelam a extrema variabilidade de todas as vogais pré-tônicas dessa locutora. 
Tabela 4 - Médias (Hz) de F1 e F2 das 5 pré-tônicas nas condições controle e teste para a locutora $\mathrm{S} 4$, do Recife

\begin{tabular}{|c|c|c|c|c|c|c|}
\hline mediana $(\mathrm{Hz}) / \mathrm{i} /$ & \multicolumn{6}{|c|}{ Palavras familiares } \\
\hline Controle & seg. /e/ & seg. $\mid \varepsilon /$ & seg. /a/ & seg. $/ \partial /$ & seg. $/ 0 /$ & seg. /u/ \\
\hline 423 & - & 447 & 530 & 387 & - & 425 \\
\hline 2483 & - & 2449 & 2411 & 2397 & - & 2240 \\
\hline mediana $(\mathrm{Hz}) / \mathrm{i} /$ & \multicolumn{6}{|c|}{ Palavras não familiares } \\
\hline Controle & seg./e/ & seg. $\mid \varepsilon /$ & seg. $/ a /$ & seg. $/ 2 /$ & seg. $/ 0 /$ & seg. /u/ \\
\hline 331 & 367 & - & 371 & 403 & - & 465 \\
\hline 2319 & 2630 & - & 2343 & 2417 & - & 2340 \\
\hline mediana $(\mathrm{Hz}) / \mathrm{e} /$ & \multicolumn{6}{|c|}{ Palavras familiares } \\
\hline Controle & seg. /i/ & seg. $\mid \varepsilon /$ & seg. $/ a /$ & seg. $/ 2 /$ & seg. $/ 0 /$ & seg. /u/ \\
\hline 466 & 472 & 614 & 727 & 606 & - & 489 \\
\hline 1788 & 2073 & 1893 & 1902 & 1884 & - & 1802 \\
\hline $\begin{array}{c}\text { Median - F2 }(\mathrm{Hz}) \\
/ \mathrm{e} /\end{array}$ & \multicolumn{6}{|c|}{ Palavras não familiares } \\
\hline Controle & seg. /i/ & seg. $\mid \varepsilon /$ & seg. /a/ & seg. $/ 0 /$ & seg. $/ 0 /$ & seg. /u/ \\
\hline 470 & 445 & 482 & - & 563 & - & 445 \\
\hline 1927 & 2250 & 2205 & - & 1951 & - & 1525 \\
\hline mediana $(\mathrm{Hz}) / \mathrm{a} /$ & \multicolumn{6}{|c|}{ Palavras familiares } \\
\hline Controle & seg. /i/ & seg. $/ \mathrm{e} /$ & seg. $|\varepsilon|$ & seg. $/ \partial /$ & seg. $/ 0 /$ & seg. /u/ \\
\hline 825 & 795 & 677 & 821 & 740 & - & 720 \\
\hline 1531 & 1691 & 1602 & 1634 & 1371 & - & 1496 \\
\hline mediana $(\mathrm{Hz}) / \mathrm{a} /$ & \multicolumn{6}{|c|}{ Palavras não familiares } \\
\hline Controle & seg. /i/ & seg. /e/ & seg. $\mid \varepsilon /$ & seg. $/ / /$ & seg. $/ 0 /$ & seg. $/ u /$ \\
\hline 819 & 719 & 756 & - & 739 & 784 & 737 \\
\hline 1323 & 1227 & 1307 & - & 1351 & 1191 & 1352 \\
\hline mediana $(\mathrm{Hz}) / \mathrm{o} /$ & \multicolumn{6}{|c|}{ Palavras familiares } \\
\hline Controle & seg. /i/ & seg. /e/ & seg. $\mid \varepsilon /$ & seg. /a/ & seg. /o/ & seg. $/ u /$ \\
\hline 483 & 499 & 514 & 536 & 591 & 572 & 520 \\
\hline 1157 & 959 & 942 & 989 & 1202 & 1059 & 1037 \\
\hline mediana $(\mathrm{Hz}) / \mathrm{o} /$ & \multicolumn{6}{|c|}{ Palavras não familiares } \\
\hline Controle & seg. /i/ & seg. /e/ & seg. $\mid \varepsilon /$ & seg. /a/ & seg. /o/ & seg. $/ u /$ \\
\hline 533 & 467 & 468 & - & 639 & 491 & 470 \\
\hline 1048 & 1024 & 1264 & - & 1109 & 1346 & 955 \\
\hline mediana $(\mathrm{Hz}) / \mathrm{u} /$ & \multicolumn{6}{|c|}{ Palavras familiares } \\
\hline Controle & seg. /i/ & seg. /e/ & seg. $\mid \varepsilon /$ & seg. /a/ & seg. /o/ & seg. $/ 0 /$ \\
\hline 415 & 399 & 405 & 454 & 408 & 503 & - \\
\hline 1326 & 1296 & 994 & 1151 & 1145 & 1385 & - \\
\hline mediana $(\mathrm{Hz}) / \mathrm{u} /$ & \multicolumn{6}{|c|}{ Palavras não familiares } \\
\hline Controle & seg. /i/ & seg. /e/ & seg. $\mid \varepsilon /$ & seg. /a/ & seg. /o/ & seg. $/ 0 /$ \\
\hline 412 & 426 & - & - & - & - & - \\
\hline 1332 & 1016 & - & - & - & - & - \\
\hline
\end{tabular}

Fonte: Dados da pesquisa 
35.2

2019

픈

¿

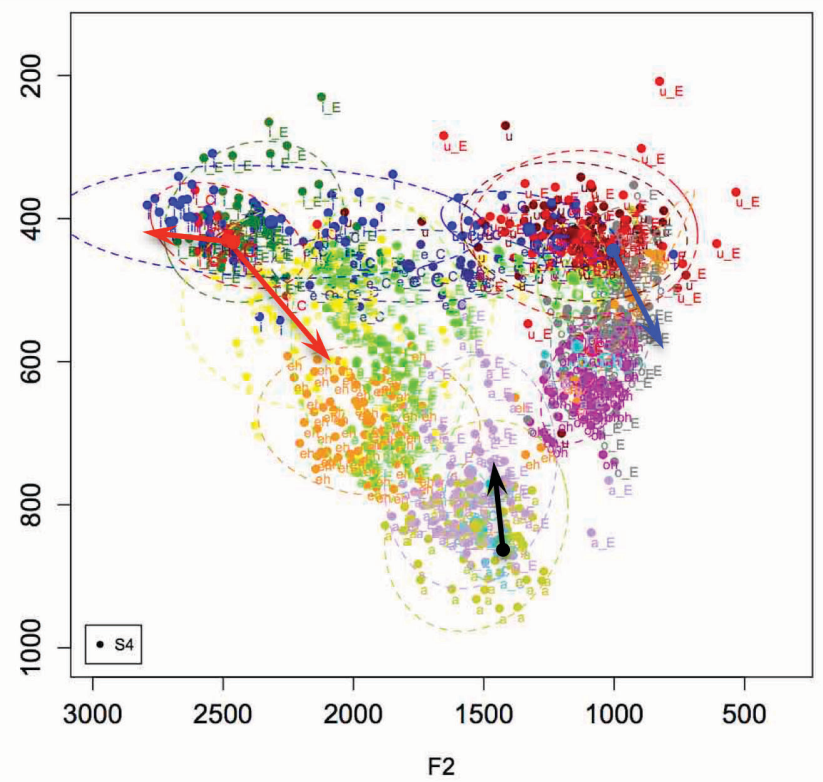

Figura 7 - Espaço acústico F1 x F2 em Hertz de S4 (feminino, PE) para palavras familiares.

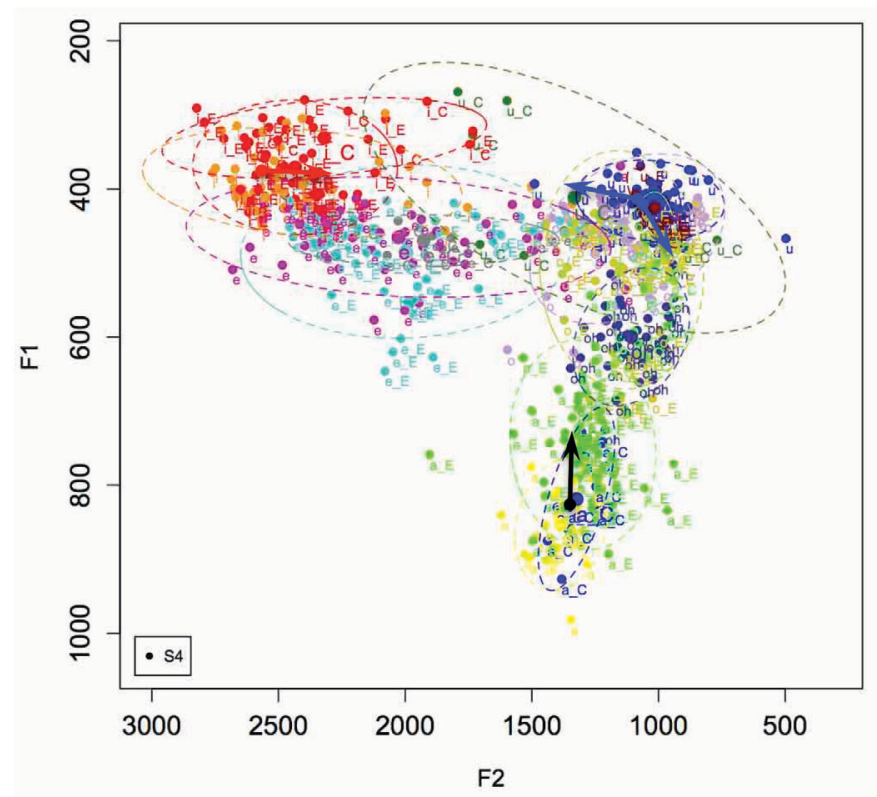

Figura 8 - Espaço acústico F1 x F2 em Hertz de S1 (feminino, PE) para palavras não familiares. 
Quanto às situações em que houve significância para os casos das pré-tônicas médias /e,o/, o exame das tabelas 3 a 6 , independentemente da familiaridade das palavras, nos mostra o que segue.

Para os locutores paulistas, o alçamento (parâmetro F1) disparado por vogal alta na tônica foi significativo 5 vezes ao ser disparado por /i/ tônico e 3 vezes por /u/, enquanto o abaixamento foi significativo 6 vezes, tanto disparado por $/ \varepsilon /$ quanto por / $/$ e por /a/. Examinando esses mesmos locutores, independentemente de gatilho, as duas vogais pré-tônicas médias /e,o/ têm 14 e 12 diferenças significativas respectivas que apontam para covariação do F1 delas com o das tônicas que as seguem. Assim, para esses locutores a hipótese 6 se confirma enquanto que a hipótese 7 aponta preferência por covariação de F1 de /e/ com a tônica.

Para as locutoras do Recife, o alçamento disparado por vogal alta na tônica foi significativo apenas 3 vezes quando disparado por /i/ e 1 por $/ \mathrm{u} /$, enquanto o abaixamento foi significativo 4 vezes disparado por $/ \varepsilon /, 7$ vezes disparado por $/ \mathrm{o} / \mathrm{e} 6$ vezes por $/ \mathrm{a} /$. Examinando nesses mesmos locutores, independentemente de gatilho, /e/ tem 12 diferenças significativas enquanto /o/ tem 9 diferenças significativas que apontam para covariação do F1 delas com o das tônicas que as seguem. Assim, para o Recife, as hipóteses 6 se confirma enquanto que a hipótese 7 aponta preferência por covariação de $\mathrm{F} 1 \mathrm{de} / \mathrm{e} /$ com a tônica. O teste de percepção relatado adiante confirma a harmonia que gera abertas em posição pré-tônica no Recife.

Examinando os 4 locutores, há assimetria na vogal que sofre harmonia, com frequência maior para /e/. O abaixamento parece ser o fenômeno mais frequente, contrariamente ao esperado, talvez por conta da faixa etária e estado da língua, especialmente no interior de São Paulo, onde talvez o fenômeno fosse menos esperado. De fato, os testes de percepção confirmam esse fato. No interior de São Paulo há perfeita simetria quanto à vogal que dispara abaixamento, com igual frequência para $/ \varepsilon, a, J /$. No Recife, entre essas três vogais a ordem de preferência do maior para o menor é $/ \supset />/ \mathrm{a} />/ \varepsilon /$. É preciso ter em mente, no entanto, para o caso do interior paulista, que há questões de variação individual que apontam para um processo em curso, possivelmente de abaixamento: o exame de mais dois locutores pareados em 
faixa etária e escolaridade com os analisados aqui, um homem e uma mulher, mostram que a locutora tende a alçar o /e/ pré-tônico diante de /i/ e o abaixar diante de / $\varepsilon$, a/, enquanto que para /o/ / pré-tônico é abaixado independentemente da vogal seguinte no caso apenas das palavras familiares. Já o locutor masculino abaixa ambas as pré-tônicas diante das palavras familiares. Considerando os 4 locutores paulistas, que haja mais casos de abaixamento e especificamente para palavras familiares no caso dos últimos, sugere uma mudança em curso no sentido de prevalecer o abaixamento na região estudada.

Quanto aos dados sobre duração média de vogais pré-tônicas controle vs teste nos quatro locutores, a Tabela 5 mostra as percentagens de diferenças significativas, assinalando as que são mais curtas que as vogais pré-tônicas controle (de 48 a 95 \%) vs as mais longas que a vogal controle ( 5 a 52\%). Como não há nenhum padrão diferenciado de comportamento quando as palavras são ou não familiares, todas foram agrupadas. Não há preferência clara da influência da tônica. A duração mais curta não se dá, assim, para as vogais pré-tônicas que se alçaram diante de determinadas tônicas, como visto acima.

Tabela 5 - Percentagem de diferenças significativas para duração controle vs teste

\begin{tabular}{|c|c|c|c|c|c|}
\hline $\begin{array}{c}\text { Locutor. } \\
\text { Estado }\end{array}$ & $\begin{array}{c}\text { \# dif. sig. } \\
(\%)\end{array}$ & $\begin{array}{c}\% \text { mais } \\
\text { curtas que } \\
\text { controle }\end{array}$ & $\begin{array}{c}\text { contexto de } \\
\text { tônica para } \\
\text { mais curtas }\end{array}$ & $\begin{array}{c}\% \text { mais } \\
\text { longas que } \\
\text { controle }\end{array}$ & $\begin{array}{c}\text { contexto de } \\
\text { tônica para } \\
\text { mais longas }\end{array}$ \\
\hline LR.SP & $14(32 \%)$ & 64 & todas & 36 & $/ \mathrm{i}$ e $\mathrm{u} /$ \\
\hline RS.SP & $19(43 \%)$ & 68 & todas $-/ \mathrm{o} /$ & 32 & todas $-/ \varepsilon$ o/ \\
\hline S1.PE & $27(61 \%)$ & 48 & todas $-/ \mathrm{o} /$ & 52 & todas $-/ \mathrm{i} \mathrm{o} /$ \\
\hline S4.PE & $19(43 \%)$ & 95 & todas $-/ \mathrm{o} /$ & 5 & $\begin{array}{c}\mathrm{u} / \text { (para } / \mathrm{o} / \mathrm{na} \\
\text { pré-tônica })\end{array}$ \\
\hline
\end{tabular}

Fonte: Dados da pesquisa

\section{Testes de percepção}

Para a realização dos dois testes de percepção era preciso eliminar a influência que o léxico pudesse ter no julgamento do grau de abertura das pré-tônicas e considerar o fato que, por fazer parte de nosso 
sistema fonológico, os ouvintes são capazes de avaliar esse grau nas vogais médias /e,o/ apenas. Para eliminar a influência do léxico foram extraídas para o teste as sílabas pré-tônicas de suas palavras respectivas, delimitadas pelo fim da vogal que antecede a palavra "Digo" até o fim da vogal pré-tônica pelos mesmos critérios de delimitação de vogais apresentados acima.

Para as vogais /i, a, u/, realizamos um teste de avaliação de sua qualidade acústica, instruindo os ouvintes para que julgassem o quão essas vogais são bons exemplares delas mesmas. Isso foi feito por uma escala de Likert de cinco graus, de "muito ruim" a "muito bom", passando por "ruim", "passável" e "bom". Cada vez que o participante ouvia uma sílaba contendo uma dessas três vogais ele clicava na tela num no espaço contendo uma das palavras da escala para fazer sua avaliação. Para o segundo teste, o com as vogais médias, foi solicitado apenas que dissesse se era aberta ou fechada.

Para cada teste de percepção, foram extraídos de 15 a 18 sílabas por locutor, de forma a manter sílabas provenientes de palavras com as 7 tônicas possíveis, dando um total de 56 sílabas para o teste com /i,a,u/ e 66 sílabas para o teste com /e,o/. Os testes foram aplicados para 3 conjuntos de ouvintes, dois para paulistas (testes com /e,o/ com 30 participantes e $/ \mathrm{i}, \mathrm{a}, \mathrm{u} / \mathrm{com} 20$ participantes) e um para falantes do Recife com 20 participantes. Para os participantes do Recife aplicamos apenas o teste das vogais médias porque o teste feito com os paulistas para $/ \mathrm{i}, \mathrm{a}, \mathrm{u} /$ não se mostrou útil. Além disso, estamos interessados sobremaneira em examinar a dependência do dialeto do ouvinte para o reconhecimento do grau de abertura das vogais médias.

Os resultados do teste com /e,o/ com ouvintes paulistas para as sílabas de paulistas e recifenses revelam que os ouvintes não são sensíveis à mudança significativa de F1 de /e/ diante de tônicas altas no sentido de alçamento que LR realizou, mas apenas a mudanças no sentido de abaixamento diante de tônicas baixas para ambos os locutores. Assim, se a tônica é /i, e, o, u/, 100 \% das pré-tônicas /e,o/ são percebidas respectivamente como /e,o/ se o locutor é paulista ou recifense. Por outro lado, se a tônica era aberta ou médio-aberta $(/ \varepsilon$ a Ј/), $28 \%$ dos /e/ foram percebidos como [E] se o locutor é paulista e $78 \%$ dos /e/ foram percebidos como [є] se o locutor é do Recife. Esse 
resultado confirma o abaixamento em Recife quando seguido dessas tônicas para os ouvintes paulistas. Quanto aos /o/ pré-tônicos diante de $/ \varepsilon$ a $\supset /, 50 \%$ deles foram percebidos como [৩] se sílaba de paulista ou de locutora do Recife. Das sílabas de paulistas, $40 \%$ desses $50 \%$ foram sílabas da locutora feminina.

Os resultados do teste com /e,o/ com ouvintes do Recife foram exatamente os mesmos para as pré-tônicas /e/ e para pré-tônicas /o/ diante de fechadas e para o /e/ diante de aberta, mas um padrão diferente foi encontrado para as pré-tônicas /o/ diante de abertas e médio-abertas: 50 $\%$ deles foram percebidos como [॰] se sílaba de paulista e $83 \%$ como [○] de locutora do Recife. Essa assimetria entre os ouvintes demonstra uma tendência para ouvintes do Recife a perceberem posteriores como baixas em geral, $33 \%$ a mais que ouvintes paulistas para exatamente os mesmos estímulos.

\section{Discussão}

O que ressalta do confronto dos dados do interior de São Paulo com os do Recife, tanto pela análise estatística - que assinala os contextos das diferenças significativas com maior frequência de altura -, quanto pelas figuras 1 a 8 é o fato de que as pré-tônicas /e o/ nos dados das locutoras do Recife ocupam região de dispersão semelhantes com as respectivas tônicas /\& J/, o que não ocorre com os dados dos locutores do interior de São Paulo, embora, em vários casos de movam para as regiões dessas mesmas tônicas.

Do exposto acima para os dados de produção, observamos que as vogais pré-tônicas com valores médios de F1 e F2 mais frequentemente significativos são /e o a/. As vogais altas /i u/ do conjunto de teste, especialmente no Recife, são menos afetadas em média com relação às vogais $/ \mathrm{i} \mathrm{u} /$ controle, embora essas sejam bastante dispersas na locutora S4 do Recife.

As palavras familiares são mais afetadas pelo contexto das tônicas do que as não familiares, em todos os locutores. Embora, como se depreende das figuras, ocorra coarticulação vogal a vogal também nesse caso. Quando às locutoras do Recife, em particular, ocorre produção das vogais /e o/ como [ $\varepsilon$ ○] tanto em palavras familiares como nas não 
familiares: as locutoras S1 e S4 abaixam /e/, ocupando então o espaço

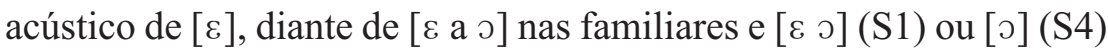
nas não familiares. Quanto à vogal /o/, também se abaixa diante de [є a ว] (S1) e [a つ] (S4) nas familiares, enquanto nas não familiares se abaixa diante de [a o] (S1) e [a] (S4). Esse padrão caracteriza que há uma vogal tônica baixa ou médio-baixa que dispara o fenômeno nas locutoras do Recife. Não há realização de /e o/ como médio-baixa independentemente do contexto, pois não abaixa, quando a tônica é /i u/ (pelo contrário, nas não familiares as vogais médias se alçam em S4 diante dessas tônicas. Esses resultados de abaixamento harmônico confirmam o que se encontra nos dados para Recife também examinados por Sandalo (2012), trabalho que também avaliou a harmonia com /a/ para esta localidade. Em S1 o abaixamento de /e/ diante de palavra familiar com / $\mathrm{u}$ / tônico é de pequena extensão para ser audível, o que foi confirmado pelo teste de percepção (palavra "verruga"). De fato, o teste de percepção revelou que todas as palavras com vogais médias /e,o/ na pré-tônica foram percebidas como /e,o/ se a tônica era fechada (alta).

Quanto ao último comportamento, os locutores do interior de São Paulo têm duas pré-tônicas mais afetadas diante das tônicas altas nos dois tipos de palavras, sendo sempre alçadas nesse contexto.

Diante do exposto podemos responder às sete hipóteses acima, como segue:

1. Confirmada a hipótese 1 de que palavras familiares harmonizam mais que palavras não familiares. Os dados revelam que há um maior número de diferenças significativas quando as vogais pré-tônicas são de palavras familiares, consideradas de acordo com a tônica seguinte.

2. Não confirmada a hipótese 2 de que a harmonia é semelhante nos dois dialetos, mas está associada ao abaixamento na pré-tônica não motivado pela tônica no dialeto do Recife. De fato, nem a harmonia é semelhante, pois vimos a realização das vogais pré-tônicas /e o/, em particular, das locutoras do Recife como tônicas médio-baixas, nem se abaixam independentemente das tônicas: é apenas diante de tônicas baixa e médio-baixas que as pré-tônicas /e o/ abaixam.

3. Não confirmada a hipótese 3 de que palavras proeminentes, por serem hiperarticuladas, devem desfavorecer a harmonia vocálica, pois não há diferença condicionadas ao nível de proeminência nos dados. 
4. Confirmada a hipótese 4 de que não há efeito de posição do enunciado, pois esse fator não foi significativo.

5. Também não confirmada a hipótese 5 de que pré-tônicas /e,o/ que se alçam para qualidade acústica semelhante à da tônica alta que dispara o processo devem ter duração menor que na condição controle, enquanto pré-tônicas /e,o/ que abaixam disparadas por vogais baixas ou médio-baixas devem ter duração maior do que na condição controle. De fato, não há esse padrão nas vogais da condição teste, a não ser que tendem a serem mais curtas que na situação controle independentemente de condicionantes.

6. Confirmada a hipótese 6 de que a tônica /u/ serve de gatilho de harmonia com menor frequência que a vogal /i/, no caso de alçamento.

7. Não confirmada a hipótese 7 de que as vogais pré-tônicas /e,o/ têm igual frequência de harmonização. Em nossos dados /e/ harmoniza mais que $/ \mathrm{o} /$.

Quanto às questões colocadas acima, a resposta é positiva para ambas: tanto o fenômeno da harmonia é distinto entre os dialetos examinados aqui quanto a familiaridade das palavras condiciona a frequência do processo.

\section{Agradecimentos}

Aos nossos locutores e à aluna Cássia Sanches pela ajuda com as gravações, segmentações e testes estatísticos e a Magnum Madruga por aplicar o teste de familiaridade. $\mathrm{O}$ trabalho se insere no projeto temático "Fronteiras e Assimetrias em Fonologia e Morfologia", proc. FAPESP 2012/17869-7 e bolsa CNPq do primeiro autor "Análise prosódico-acústica da fala espontânea e da ironia na fala atuada", proc. $n^{\circ} 302657 / 2015-0$.

\section{Referências}

ABAURRE, M. B. 1981. Processos fonológicos segmentais como índices de padrões prosódicos diversos nos estilos formal e casual do português do Brasil. Caderno de Estudos Lingüísticos, 2: 23-34. 
ABRY, C.; LALLOUACHE, T. 1995. Le MEM: un modèle d'anticipation paramétrable par locuteur: Données sur l'arrondissement en français. Bulletin de la communication parlée, 3, 85-89.

BARBOSA, P. A. 2016. VowelParameterComputing. Programa de software. Disponível com o autor.

BISOL, L. A. 2015. A harmonização vocálica como indício de uma mudança histórica. D.E.L.T.A., 31(1): 185-205.

BISOL, L. 1988. A harmonização vocálica na fala culta. DELTA: Documentação de estudos em linguística teórica e aplicada. 4(1): 1-20.

BISOL, L. 1981. Harmonia Vocálica: Uma regra variável. Tese de Doutorado. Faculdade de Letras/UFRJ, Rio de Janeiro.

BOERSMA, P.; WEENINK, D. 2015. Praat: doing phonetics by computer. Versão 6.0.06. Disponível em: www.praat.org.

CALLOU, D.; MORAES, J.; LEITE, Y.; MACHADO, L. 2009. Caracterização acústica das vogais no português brasileiro: sílabas pretônicas e tônicas. In: HORA, D. da. Vogais no ponto mais oriental das Américas. João Pessoa: Idéia/Editora Universitária UFPB, p. 133-144.

COLLISCHONN, G., SILVA, M. E. 2013. Elevação das médias pretônicas por harmonia: questões teóricas e empíricas. Work. Pap. Linguíst., 13(2): 01-14, Florianópolis, abr/jul.

FOWLER, C. 1980. Coarticulation and theories of extrinsic timing. $J$ of Phonetics, 8: 113-133.

HARDCASTLE, W. J.; HEWLETT, N. (eds.). 1999. Coarticulation: Theory, data and techniques. Cambridge, UK: Cambridge University Press.

HORA, D. da. 2005. Uso variável das vogais no português do Brasil. Manuscrito.

KENSTOWICZ, M.; SANDALO, F. 2016. Pretonic Vowel Reduction in Brazilian Portuguese: Harmony and Dispersion. Journal of Portuguese Linguistics, 15, 6. DOI: http://doi.org/10.5334/jpl.7

LEE, S.-H.; OLIVEIRA, M. A. de. 2003. Variação Inter- e Intra-Dialetal no Português Brasileiro: Um Problema para a Teoria Fonológica. In: HORA, D. da; COLLISCHONN, G. (org.). Teoria Linguística: fonologia e outros temas. João Pessoa: Editora Universitária da UFPB, v., p. 67-91.

MANUEL, S. Y.; KRAKOW, R. A. 1984. Universal and language particular aspects of vowel-to-vowel coarticulation. Haskins Laboratories Status Report on Speech Research, SR-77/78, 69-78.

SANDALO, M. F. S. 2012. Harmonia e redução vocálica no português do Brasil. Letras de Hoje, 47 (3), p. 268-274. 
35.2

2019

SCHWINDT, Luiz Carlos S. 2002. A regra variável de harmonização vocálica no RS. In: BISOL, L.; BRESCANCINI, C.R. (orgs.). Fonologia e variação: recortes do português brasileiro. Porto Alegre: EDIPUCRS.

Recebido em: 01/02/2017 Aprovado em: 04/10/2017 